ISSN : $2302-1590$

E-ISSN: $2460-190 \mathrm{X}$

ECONOMICA

Journal of Economic and Economic Education Vol.5 No.1 (39 - 46)

\title{
MODEL PEMBELAJARAN MAKE A MATCH DAN PENGARUNHYA TERHADAP HASIL BELAJAR EKONOMI DI SMAN 14 PADANG
}

\author{
Sri Wahyuni \\ Dosen Program Studi Pendidikan Ekonomi STKIP-PGRI Sumbar \\ Jl. Gunung Pangilun No. 1 Padang Sumatera Barat \\ E-mail: Sriwahyuniajeng@gmail.com
}

submited: 2016.07.16 reviewed: 2016.08.15 accepted: 2016.11.09

http://dx.doi.org/10.22202/economica.2016.v5.i1.689

\begin{abstract}
This study aims to look at the effect of learning model Make amatch the learning outcomes of economic class X SMAN 14 Padang. This research is a classroom action research (PTK), which in a given class action (action). Within a given class action to rectify a situation where in the learning process seen still low activity of students in learning and lead to low learning outcomes. The location of this research is SMAN 14 Indarung Padang Jalan Karang Putih. Where Yang became the object of this research is class $X 1$. The design of the study is a research spiral, one round consists of the following steps: Planning (planning), that preparations are underway for the implementation of the (PTK). Based on the above data, the make-AMatch learning model can improve the results of the economic study of students at SMAN 14 Padang. Therefore it can be concluded as follows: Learning Outcomes of students has increased from cycle one, cycle two and cycle three. With the implementation of this learning model Make Amatch their significant influence between the learning model make-Amatch on learning outcomes of economics graders X1 SMA 14 Padang. With so this learning model can be used for the nexteconomiclearningprocess.
\end{abstract}

\begin{abstract}
Abstrak
Penelitian ini bertujuan untuk melihat pengaruh model pembelajaran Make amatch terhadap hasil belajar ekonomi kelas X SMAN 14 Padang. Jenis penelitian ini adalah penelitian tindakan kelas (PTK), dimana dalam suatu kelas diberikan tindakan (action). Dalam satu kelas diberikan tindakan untuk memperbaiki suatu keadaan dimana dalam proses pembelajaran dilihat masih rendahnya aktivitas siswa dalam pembelajaran dan menyebabkan hasil Belajar rendah. Lokasi Tempat penelitian ini adalah SMAN 14 Padang Jalan Indarung Karang Putih. Dimana Yang menjadi objek Penelitian ini adalah kelas XI. Rancangan penelitian yang digunakan adalah penelitian spiral, satu putaran terdiri dari langkah-langkah sebagai berikut: Perencanaan (planning), yakni persiapan yang dilakukan untuk pelaksanaan PTK. Berdasarkan dari data diatas maka model pembelajaran make AMatch dapat meningkatkan hasil Belajar ekonomi siswa di SMAN 14 Padang. Untuk itu dapat ditarik kesimpulan sebagai berikut: Hasil Belajar siswa mengalami peningkatan dari siklus satu, siklus dua dan siklus tiga. Dengan adanya penerapan model pembelajaran Make Amatch ini adanya pengaruh yang siknifikan antara model pembelajaran make Amatch terhadap hasil belajar ekonomi siswa kelas X1 SMA 14 Padang. Dengan Demikian Model pembelajaran ini bisa digunakan untuk proses pembelajaran ekonomi berikutnya.
\end{abstract}

Keywords: Make Model Amatch

C2016 Prodi Pendidikan Ekonomi STKIP PGRI, Padang 


\section{PENDAHULUAN}

Kegiatan Belajar Mengajar merupakan kegiatan yang paling pokok dilakukan dalam keseluruhan proses pendidikan di Sekolah. Keberhasilan dalam pendidikan terutama ditentukan oleh proses belajar mengajar yang dialami siswa di kelas maupun diluar kelas. Hal ini terlihat dari metode yang digunakan guru. Salah satu metode yang sering digunakan oleh guru adalah metode konvensional dimana pembelajaran masah berpusat pada guru.

Pembelajaran terpusat pada guru sampai saat ini masih menemukan beberapa kelemahan. Kelemahan tersebut dapat dilihat pada saat berlangsungnya proses pembelajaran di kelas, interaksi aktif antara siswa dengan guru atau siswa dengan siswa jarang terjadi. Siswa kurang terampil menjawab pertanyaan atau bertanya tentang konsep yang diajarkan. Siswa kurang bisa bekerja dalam kelompok diskusi dan pemecahan masalah yang diberikan. Mereka cenderung belajar sendirisendiri. Pengetahuan yang didapat bukan dibangun sendiri secara bertahap oleh siswa atas dasar pemahaman sendiri. Karena siswa jarang menemukan jawaban atas permasalahan atau konsep yang dipelajari.

Menyadari bahwa ekonomi merupakan cabang ilmu yang memberikan kontribusi yang cukup besar terhadap kebutuhan manusia. Maka sepatutnya pembelajaran ekonomi diminati oleh siswa. Namun kenyataan yang terjadi disekolah SMA......mata pelajaran ekonomi merupakan mata pelajaran yang kurang disukai siswa, dimana dalam pembelajar ekonomi masih banyak siswa yang ngobrol, tidur, mengerjakan tugas selain pelajaran ekonomi sewaktu mereka belajar ekonomi. Kurangnya motivasi siswa dalam belajar ekonomi salah satunya disebabkan oleh metode pembelajaran yang dilakukan guru yang membosan kan seperti metode ceramah

Setelah dilakukan evaluasi terhadap hasil belajar siswa dikelas $\mathrm{X}$ SMAN 14 Padang ternyata dengan pendekatan pembelajaran yang dilakukan guru belum memadai sehingga hasil belajar siswa dirasa belum maksimal. Hal ini tampak pada pencapaian nilai akhir siswa. Dalam satu tahun belakangan ini siswa yang memperoleh nilai $60 \mathrm{ke}$ atas tidak lebih dari $25 \%$.Rendahnya pencapaian nilai akhir siswa ini, menjadi indikasi bahwa pembelajaran yang dilakukan selama ini belum efektif. Nilai akhir dari evaluasi belajar belum mencakup penampilan dan partisipasi siswa dalam pembelajaran, hingga sulit untuk mengukur keterampilan siswa.

Untuk memperbaiki hal tersebut perlu disusun suatu pendekatan dalam pembelajaran yang lebih komprehensip dan dapat mengaitkan materi teori dengan kenyataan yang ada di lingkungan sekitarnya. Atas dasar itulah peneliti mencoba mengembangkan pendekatan kooperatif dalam pembelajaran dengan metode make a match. Dimana dalam metode make a match atau mencari pasangan ini merupakan salah satu model pembelajaran yang bisa meningkatkan aktifitas siswa karena dalam metode tersebut ada unsur permainan yang bisa membuat siswa senang dalam proses pembelajaran. Berdasarkan Permasalah diatas Maka peneliti tertarik melakukan penelitian dengan judul "Model pembelajaran Make Amatch Dan Pengaruhnya Terhadap Hasil Belajar Ekonomi SMAN 14 Padang.

\section{A. Hasil Belajar Siswa}


Belajar dan mengajar merupakan konsep yang tidak bisa dipisahkan. Belajar merujuk pada apa yang harus dilakukan seseorang sebagai subyek dalam belajar. Sedangkan mengajar merujuk pada apa yang seharusnya dilakukan seseorang guru sebagai pengajar. Dua konsep belajar mengajar yang dilakukan oleh siswa dan guru terpadu dalam satu kegiatan. Diantara keduannya itu terjadi interaksi dengan guru. Kemampuan yang dimiliki siswa dari proses belajar mengajar saja harus bisa mendapatkan hasil bisa juga melalui kreatifitas seseorang itu tanpa adanya intervensi orang lain sebagai pengajar.

Oleh karena itu hasil belajar merupakan kemampuankemampuan yang dimiliki seorang siswa setelah ia menerima perlakukan dari pengajar (guru), seperti yang dikemukakan oleh Sudjana: Hasil belajar adalah kemampuan-kemampuan yang dimiliki siswa setelah menerima pengalaman belajarnya (Sudjana, 2004 : 22). Sedangkan menurut Horwart Kingsley dalam Sudjana membagi tiga macam hasil belajar mengajar : (1). Keterampilan dan kebiasaan, (2). Pengetahuan dan pengarahan, (3). Sikap dan cita-cita (Sudjana, 2004 : 22).

Dari pendapat di atas dapat disimpulkan bahwa hasil belajar adalah kemampuan keterampilan, sikap dan keterampilan yang diperoleh siswa setelah ia menerima perlakuan yang diberikan oleh guru sehingga dapat mengkonstruksikan pengetahuan itu dalam kehidupan sehari-hari.

Adapun Faktor-faktor yang mempengaruhi hasil belajar yaitu: Secara implisit, ada dua faktor yang mempengaruhi hasil belajar anak, yaitu faktor internal dan faktor eksternal a. Faktor Internal
Foktor internal meliputi faktor fisiologis, yaitu kondisi jasmani dan keadaan fungsi-fungsi fisiologis. Faktor fisiologis sangat menunjang atau melatar belakangi aktivitas belajar. Keadaan jasmani yang sehat akan lain pengaruhnya dibanding jasmani yang keadaannya kurang sehat. Untuk menjaga agar keadaan jasmani tetap sehat, nutrisi harus cukup. Hal ini disebabkan, kekurangan kadar makanan akan mengakibatkan keadaan jasmani lemah yang mengakibatkan lekas mengantuk dan lelah.

Faktor psikologis, yaitu yang mendorong atau memotivasi belajar. Faktor-faktor tersebut diantaranya:

- Adanya keinginan untuk tahu

- Agar mendapatkan simpati dari orang lain.

- Untuk memperbaiki kegagalan

- Untuk mendapatkan rasa aman.

b. Faktor Eksternal

Faktor-faktor eksternal, yaitu faktor dari luar diri anak yang ikut mempengaruhi belajar anak, yang antara lain berasal dari orang tua, sekolah, dan masyarakat.

1) Faktor yang berasal dari orang tua

Faktor yang berasal dari orang tua ini utamanya adalah sebagi cara mendidik orang tua terhadap anaknya. Dlam hal ini dapat dikaitkan suatu teori, apakah orang tua mendidik secara demokratis, pseudo demokratis, otoriter, atau cara laisses faire. Cara atau tipe mendidik yang dimikian masing-masing mempunyai kebaikannya dan ada pula kekurangannya.

Dalam kaitan dengan hal ini, Tim Penyusun Buku Sekolah Pendidikan Guru Jawa Timur (1989: 8) menyebutkan, "Di dalam pergaulan di lingkungan keluarga hendaknya berubah menjadi situasi pendidikan, yaitu bila orang tua memperhatikan anak, misalnya 
anak ditegur dan diberi pujian...." Pendek kata, motivasi, perhatian, dan kepedulian orang tua akan memberikan semangat untuk belajar bagi anak.

2) Faktor yang berasal dari sekolah

Faktor yang berasal dari sekolah, dapat berasal dari guru, mata pelajaran yang ditempuh, dan metode yang diterapkan. Faktor guru banyak menjadi penyebab kegagalan belajar anak, yaitu yang menyangkut kepribadian guru, kemampuan mengajarnya. Terhadap mata pelajaran, karena kebanyakan anak memusatkan perhatianya kepada yang diminati saja, sehingga mengakibatkan nilai yang diperolehnya tidak sesuai dengan yang diharapkan. Keterampilan, kemampuan, dan kemauan belajar anak tidak dapat dilepaskan dari pengaruh atau campur tangan orang lain. Oleh karena itu menjadi tugas guru untuk membimbing anak dalam belajar.

3) Faktor yang berasal dari masyarakat

Anak tidak lepas dari kehidupan masyarakat. Faktor masyarakat bahkan sangat kuat pengaruhnya terhadap pendidikan anak. Pengaruh masyarakat bahkan sulit dikendalikan. Mendukung atau tidak mendukung perkembangan anak, masyarakat juga ikut mempengaruhi.

Selain beberapa faktor internal dan eksternal di atas, faktor yang mempengaruhi hasil belajar dapat disebutkan sebagai berikut:

1) Minat

Seorang yang tidak berminat mempelajari sesuatu tidak akan berhasil dengan baik, tetapi kalau seseorang memiliki minat terhadap objek masalah maka dapat diharakan hasilnya baik. Masalahnya adalah bagainama seorang pendidik selektif dalam menentukan atau memilih masalah atau materi pelajaran yang menarik siswa. Berikutnya mengemas materi yang dipilih dengan metode yang menarik. Karena itu pendidik/ pengajar perlu mengenali karakteristik siswa, misalnya latar belakang sosial ekonomi, keyakinan, kemampuan, dan lain-lain.

2) Kecerdasan

Kecerdasan memegang peranan penting dalam menentukan berhasil tidaknya seserorang. Orang pada umumnya lebih mampu belajar daripada orang yang kurang cerdas. Berbagai penelitian menunjukkan hubungan yang erat antara tingkat kecerdasan dan hasil belajar di sekalah (Sumadi, 1989: 11).

3) Bakat

Bakat merupakan kemampuan bawaan sebagai potensi yang perlu dilatih dan dikembangkan agar dapat terwujud (Utami, 1992: 17). Bakat memerlukan latihan dan pendidikan agar suatu tindakan dapat dilakukan pada masa yang akan datang. Selain kecerdasan bakat merupakan faktor yang menentukan berhasil tidaknya seseorang dalam belajar (Sumadi, 1989: 12). Belajar pada bidang yang sesuai dengan bakatnya akan memperbesar kemungkinan seseorang untuk berhasil.

4) Motivasi

Motivasi merupakan dorongan yang ada pada diri anak untuk melakukan sesuatu tindakan. Besar kecilnya motivasi banyak dipengaruhi oleh kebutuhan individu yang ingin dipenuhi (Suharsimi, 1993: 88). Ada dua macam motivasi yaitu motivasi instrinsik dan motivasi ekstrinsik. Motivasi instrinsik adalah motivasi yang ditimbulkan dari dalam diri orang yang bersangkutan. Sedangkan, motivasi ekstrinsik adalah motivasi yang timbul oleh rangsangan dari luar atau motivasi yang disebabkan oleh faktor-faktor dari luar situasi belajar, misalnya angka, ijazah, tingkatan, hadiah, persaingan, pertentangan, sindiran, cemoohan dan 
hukuman. Motivasi ini tetap diperlukan di sekolah karena tidak semua pelajaran sesuai dengan minat dan kebutuhan siswa.

Dengan memiliki kemampuan pada suatu mata pelajaran, baik itu pengetahuan, keterampilan dan sikap yang mampu dikembangkan, siswa diharapkan dapat mengalih gunakan kemampuan-kemampuan tersebut dalam mengahadapi masalah-masalah dalam berbagai bidang pelajaran. Kemampuan bernalar, kemampuan memilih strategi yang cocok dengan permasalahannya, maupun kemampuan menerima dan mengemukakan suatu informasi secara tetap dan cermat merupakan kemampuan umum yang dapat digunakan dalam berbagai bidang.

Berkaitan dengan kemampuan yang diperoleh siswa sebagai hasil belajar. Bloom yang dikutipa Djafar (2001; 83) membagi hasil belajar dalam tiga ranah kawasan yaitu:

a) Ranah kognitif, yang meliputi pengetahuan, pemahaman, penerapan, analisis dan penilaian

b) Ranah Afektif, mencakup penerimaan, partisipasi, penilaian atau penentuan sikap, organisasi dan pembentukan pola hidup

c) Ranah Spikomotor, terdiri dari persepsi, kesiapan: gerakan terbimbing, gerakan terbiasa, gerakan kompleks dan penyesuaian pola gerakan dan kreativitas

Dari pendapat diatas dapat disimpulkan, jika seseorang telah melakukan kegiatan belajar, maka ia akan memperoleh kemampuan yang mencakup pengetahuan, sikap dan keterampilan sehingga akan terjadi perubahan dalam dirinya. Hasil belajar ini dapat diukur dengan penilaian/ evaluasi. Penilaian kognitif dilakukan pada akhir pembelajaran dengan pemberian tes hasil belajar. Hasil belajar yang diperoleh dari tes yang dilaksanakan dapat berupa tes tertulis dan tes lisan. Pada penilaian ranah afektif dilakukan selama proses pembelajaran dengan mengacu pada indicator penilaian afektif.

\section{B. Model Make A Match}

Menurut Lorna Curran 1994, Model pembelajaran Make A Match adalah model pembelajaran mencari pasangan. Setiap siswa mendapat sebuah kartu (bisa soal atau jawaban) lalu secepatnya mencari pasangan yang sesuai dengan kartu yang ia pegang. Dalam pembelajaran Make A Match sangat asyik dan menyenangkan.

Adapun langkah-langkah Make A match menurut Lorna Curan (2000) adalah sebagai berikut:

1. Guru menyiapkan beberapa kartu yang berisi beberapa konsep atau topic yang cocok untuk sesi reviu, satu bagian kartu soal dan bagian lainnya kartu jawaban.

2. Setiap siswa mendapatkan sebuah kartu yang bertuliskan soal jawaban

3. Tiap siswa memikirkan jawaban soal dari kartu yang di pegang.

4. Setiap siswa mencari pasangan kartu yang cocok dengan kartunya

5. Setiap siswa yang dapat mencocokan kartunya sebelum batas waktu diberi poin

6. Jika siswa tidak bisa mencocokan kartunya dengan kartu temannya maka siswa tersebut akan diberikan hukuman sesuai dengan kesepakatan yang telah ditentukan

7. Setelah satu babak kartu di kocok lagi agar tiap siswa mendapatkan 
kartu yang berbeda dari sebelumnya

8. Guru bersama-sama siswa membuat kesimpulan terhadap materi pembelajaran.

Kelebihan dari Metode Make A match ini adalah (1) Dapat meningkat aktifiats belajar siswa baik secara kognitif maupun fisisk karena ada unsur permainan didalamnya (2) Metode Make A Match ini menyenangkan (3) Dapat meningkatkan pemehaman siswa terhadap materi yang dipelajari (4) Dapat meningkatkan motifasi belajar siswa (5) Metode ini efektif sebagai sarana melatih keberanian siswa untuk tampil berprestasi (6) Metode ini dapat melatih siswa untuk disiplin dalam menghargai waktu

Yang harus diperhatikan dalam model Make A match ini adalah: (1) Kalau model ini tidak dirancang maka waktu akan banyak terbuang (2) Pada awal penerapan metode ini, banyak siswa yang malu untuk berpasangan dengan lawan jenis, oleh sebab itu dibutuhkan pengarahan guru dalam metode ini (3) Kalau siswa tidak diarahkan dengan baik pada saat persentase banyak siswa yang tidak memperhatikan (4) Dalam metode ini guru harus hati-hati dan bijaksana saat memberikan hukuman kepada siswa.

\section{Hipotesis Penelitian}

Berdasarkan kerangka konseptual diatas maka hipotesis dalam penelitian ini adalah: " Model Pembelajaran Make A Match dapat meningkatkan hasil belajar Ekonomi Kelas X SMAN 14 Padang.

\section{METODE PENELITIAN}

Jenis penelitian ini adalah penelitian tindakan kelas (PTK), dimana dalam suatu kelas diberikan tindakan (action).
Dalam satu kelas diberikan tindakan untuk memperbaiki suatu keadaan dimana dalam proses pembelajaran dilihat masih rendahnya aktivitas siswa dalam pembelajaran dan menyebabkan kelas menjadi fasif.

Pendekatan yang digunakan pada penelitian ini adalah deskritif kuantitatif. Pendekatan desktitig kuantitif menurut Ari Kunto (2006:12) penelitian yang menggunakan angka, mulai dari pengunpulan data, penafsiran terhadap datatersebut serta hailnya nanti.

Dari pernyataan diatas dapat diambil kesimpulan bahwa dalam penelitian Tindakan Kelas (PTK) guru dapat meneliti sendiri pratek pembelajaran yang dilakukan di kelas, sehingga guru dapat memperbaiki dan meningkatkan pratek-pratek pembelajaran menjadi lebih selektif.

Lokasi Penelitian : dimana penelitian ini dilakukan di SMAN 14 Padang di Indarung karang putih pada kelas X1. Prosedur Penelitian: penelitian ini merupakan penelitian tindakan kelas maka perlu dibuat rancangan penelitian agarr penelitian terlaksana dengan baik. Rancangan penelitian yang digunakan adalah penelitian spiral, satu putaran terdiri dari langkah-langkah sebagai berikut:1) Perencanaan (planning), yakni persiapan yang dilakukan untuk pelaksanaan PTK, seperti: penyusunan skenario pembelajaran, pembuatan media. 2) Tindakan (acting), yaitu deskripsi tindakan yang akan dilakukan, skenario kerja tindakan perbaikan yang akan dikerjakan, dan prosedur tindakan yang akan diterapkan. 3) Observasi (observing), yaitu kegiatan mengamati dampak atas tindakan yang dilakukan. Kegiatan ini dapat dilakukan dengan cara pengamatan, wawancara, kuesioner atau cara lain yang sesuai dengan data yang 
4) Refleksi (reflecting), yaitu kegiatan evaluasi tentang perubahan yang terjadi atau hasil yang diperoleh atas data yang terhimpun sebagai bentuk dampak tindakan yang telah dirancang. Berdasarkan langkah ini akan dapat diketahui perubahan yang terjadi dan dilakukan telaah mengapa, bagaimana, dan sejauhmana tindakan yang ditetapkan mampu mencapai perubahan atau mengatasi masalah secara signifikan. Bertolak dari refleksi ini pula suatu perbaikan tindakan dalam bentuk replanning dapat dilakukan.

\section{PEMBAHASAN}

Berdasarkan Analisa data terhadap Aktivitas siswa dalam proses pembelajaran menggunakan model pembelajaran Make Amatch pada aspek mendengarkan guru pada saat penyampaai materi mendapatkan skor rata-rata 2,8 pada siklus satu dengan kategori baik. Sedangkan pada siklus II skor Rata-rata yang diperoleh sebesar 3,06 dikategorikan baik, sedang kan untuk siklus III skor rata-rata mengalami kenaikan sebesar 3,75 di kategorikan sangat baik. Dari hal tersebut dapat dilihat siswa antusias dalam mendengarkan penjelasan guru pada saat proses pembelajaran.

Pada Saat berdikusi mencari jawaban skor rata-rata yang diperoleh pada siklus I dan siklus dua cukup baik. Hal ini terjadi karena antar siswa ini kurangnya interaksi. Pada siklus III mengalami peningkatan dengan skor rata-rata 3,6 di kategorikan sangan Baik.

Pada aspek menyampaikan ide pada siklus I skor rata-rata yang diperoleh 2,4 dengan kategori cukup baik, sedangkan pada siklus II mengalami mepningkatan dengan skor rata-rata 3,0 dengan kategori Baik sedangkan untuk siklus III mengalami peningkatan sebesar 3,73 dengan kategori Baik sekali.

Pada Aktivitas siswa pada saat mencari pasangan kartu didepan kelas pada siklus satu skor rata-rata yang diperoleh sebesar 2,3 dengan kategori cukup baik, sedangkan pada siklus II mengalami peningkatan sebesar 2,80 dengan kategori baik. Sedangkan untuk siklus III mengalami peningkatan sebesar 3,67 dengan kategori sangat baik.

Pada Aspek merangkum materi oleh siswa setelah skor rata-rata yang diperoleh pada siklus I yaitu 2,1 kategori cukup baik, sedangkan siklus dua mengalami peningkatan sebesar 2, 89 dengan kategori Baik sedangkan untuk siklus III mengalami peningkatan sebesar 3,89 dengan kategori Sangat baik. Hal ini dapat dilihat terjadinya peningakata dari siklus pertama sampai siklus ke tiga.

Untuk hasil belajar siswa dari siklus I sampai Siklus III mengalami peningkatan dilihta dari nilai rata-rata pada siklus I sebesar 65,06 siklus II mengalami peningkatan sebesar 70,10 sedang pada siklus III juga mengalami peningkatan sebesar 79,50 telah memenuhi Kriteria ketuntasan mata pelajaran Ekonomi kelas X.

\section{PENUTUP}

\section{Kesimpulan}

Berdasarkan dari data diatas maka model pembelajaran make AMatch dapat meningkatkan hasil Belajar ekonomi siswa di SMAN 14 Padang. Untuk itu dapat ditarik kesimpulan sebagai berikut: Hasil Belajar siswa mengalami peningkatan dari siklus satu, siklus dua dan siklus tiga. Dengan adanya penerapan model pembelajaran Make Amatch ini adanya pengaruh yang 
siknifikan antara model pembelajaran make Amatch terhadap hasil belajar ekonomi siswa SMA 14 Padang. Dengan Demikian Model pembelajaran ini bisa digunakan untuk proses pembelajaran berikutnya.

\section{Saran}

Berdasarkan Penelitian yang dilakukan di SMAN 14 Padang Maka dapat dikemukakan saran sebagai berikut: 1) Penelitian ini terbatas masih menggunakan mata pelajaran ekonomi tapi tidak semua model pembelajaran ini bisa digunakan dalam proses pembelajaran 2) Dalam model ini dibutuhkan keterampilan guru dalam melakukan pengelolaan lelas. Karena dalam model ini siswa aktif sehingga proses pembelajaran menjadi ribut untuk itu dibutuhkan keterampilan guru dalam melakukan pengelolaan kelas. 3) Guru harus memberikan motivasi kepada siswa dalam proses pembelajaran karena dalam model ini siswa dituntut aktif 4) Dalam menggunakan model Make Amatch ini guru harus memperhatikan waktu

\section{DAFTAR PUSTAKA}

$\underline{10.22202 / \text { economica.2016.v5.i1.689 }}$

Arikunto, Suharsimi.2006. Prosedur Penelitian Suatu Pendidikan Pendekatan Pratek. Jakarta. Rinika Cipta

Arikunto, Suharsimi. 2006. DasarDasar Evaluasi Pendidikan. Jakarta: Bumi Aksara

Aunurrahman. 2009. Belajar dan Pembelajaran. Bandung: Alfabeta

Dahar, Ratna Wilis. 2006. Teori-teori Belajar dan Pembelajaran.
Bandung: PT. Gelora Aksara Pratama.

Dimyati dan Mudjiono. 2002. Belajar dan Pembelajaran. Jakarta: Rineka Cipta

Hamalik, Oemar. 2011. Pendekatan Baru Strategi Belajar Mengajar Berdasarkan CBSA. Bandung: Sinar Baru Algensindo

Mengajar. Jakarta: Bumi Aksara

Mulyasa, E. 2010. Implementasi Kurikulum Tingkat Satuan Pendidikan Kemandirian Guru Dan Kepala Sekolah. Jakarta: Bumi Aksara

Sabri, Ahmad. 2007. Strategi Belajar Mengajar dan Micro Teaching. Jakarta: Quantum Teaching

Sanjaya, Wina. 2006. Strategi Pembelajaran Berorientasi Standar Proses Pendidikan. Jakarta: Kencana.

Silberman, Melvin L. 2006. Active Lerning: 101 Cara Belajar Siswa Aktif. Bandung: Nusamedia

Slameto. 2003. Belajar dan FaktorFaktor yang Mempengaruhi. Jakarta: Rineka Cipta

Sudjana, Nana. 2004. Penilaian Hasil Proses Belajar Mengajar. Bandung: Remaja Rosdakarya

Tim Pengembang MKDP. 2011. Kurikulum dan Pembelajaran. Jakarta: PT. Raja Grafindo Persada.

Uno, Hamzah. 2008. Model Pembelajaran. Jakarta: Bumi Aksara 